(東京大学理学部化学教室*) (昭和28年6月26日受理)

\title{
天然産硫化砒素の簡単な検出法
}

\author{
南英一・池田 長生・石森達二郎
}

\section{Simple Methods for the Detection of Natural Arsenic Sulfides}

Eitti Minami, Nagao Ikeda and Tatsujiro Ishimori (Department of Chemistry, Faculty of Science, University of Tokyo)

Simple methods of detection of arsenic sulfides, such as found in the precipitate of hot spring, are investigated; samples containing large amount of sulfur, such as flower of sulfur, are taken for finding the methods to be carried out in field test in a short time.

The following three methods gave satisfactory results.

(1) Heating of acidified silver nitrate solution and sample gives black coloration in the presence of arsenic and the presence of sulfur does not interfere the coloration. (2) Arsenic sulfide is reprecipitated by treating the sample with ammonia and nitric acid, and

\section{緒 言}

最近杤木県那須湯本温泉に著しく多量の硫化䂤素を含 さ温泉沈澱物が見出された。硫化砒素が天然に雄黄, 鵎 冠石などとして温泉地方, 火山地方の噴気孔の昇華物の 中にしばしば見出されることは周知の通りであるが，温 泉沈激物としてその存在の報告された例は極めて少くく， 本邦においては，僅かに青森県恐山温泉 ${ }^{1}$ および秋田県 玉川温泉1),2)等の記傤をみるに過ざない，一方外国にお いても合采国の Yellowstone National Park ${ }^{3}$ および Steamboat Spring4) の温泉沈澱物として報告されている程 度である. 邦須温泉, 玉川温泉のような硫化水素を含む 酸性泉は, 本邦に扣いては比較的多く, 従ってその温泉 沈澱物に多少の砒素の含まれる可能性も当然考えられ, このような試料中の砒素を現地で簡単に検出することが しばしば必要とされる。このような目的に適当するもの としては, Doelter の Handbuch ${ }^{5)}$ 中に, 硝酸銀溶液と者 沸する万法が記載されている。しかし，著者等の検討し た結果によれば，この方法では硫化砒素の外に遊離硫黄 あ同様の反応を呈することが明らかになった．したがっ て,この方法は前記の温泉でしばしば認められる硫黄華 中の硫化砣素の検出には不適当である. 篗者等は硫黄華 のような硫黄を主成分とする温泉沈澱物中の硫化砒素の 簡単な检出法を研究し，次に述べる 3 稞の方法が何れも 滿足すべき結果を与えることを示した。

\section{実験結果}

筆者等の考案した 3 方法を便宜上夫々 ( I ) 酸性硝酸 銀法, （2）硫化砒素再淡澱法および（3）砒酸銀法と名 つけることとする.これらの方法は何れも野外実験の際 の使用に適するよ5に,できるだけ試蒀の数を少くし，

\footnotetext{
*東京都交京区本富士町 1
}

the coloration with silver nitrate solution is applied for an approximate estimation of arsenic in samples containing comparatively large amount of arsenic.

(3) Detection of arsenic by the formation of silver arsenate. All of the above three methods are suitable for field test in a short time, among which (1) gives the highest sensitivity, (2) is possible for estimation of approximate content, and ( 3 ) is suitable for directive detection of arsenic; the combined use of these three methods is necessary in some cases to give effective result.

(Received, June 26, 1953)

且つ簡単な操作で短時間にできるように配虑した。

1 酸性硝酸銀法 Doelter の前記書物炕記载されてい る硝酸銀溶液と煮沸する方法に上るときは，遊離硫黄も 硫化砒素と同様の反応を呈するが，この際，硝酸銀溶液 を硫酸て酸性にすることにより，硫黄の呈色を防ぐこと ができる.

語薬 酸性硝酸銀溶液 ；硝酸銀を稀硫酸 $(1 ； 20)$ に 溶解し， $0.01 N$ (借考1) の湦度にする.

操作 試料の適当量を試験管にとり，5～10cc の酸性 硝酸銀溶液を加元て，数分間加熱惹沸する. 硫化砒素の 存在により, 試料は黒変する。(䄇考2)

限界灌度 遊離硫黄中 $0.1 \% \mathrm{As}_{2} \mathrm{~S}_{3}$

備考（1）确酸銀溶液の灌度は $0.1 \sim 0.01 \mathrm{~N}$ では問 題はないが, $0.005 N$ 程度では，加热を続けるととによ り，却って星色がうすくなるととがある。

（2）上記の操作とよる黒色化の程度は，合成物と天 然物とでは差異があり，一般に合成物は濃く黑化する。 その原因については未だ充分に明らかでないが，興味深 いことである。な把限界濃度は天然産硫化䂤素を硫黄で 稀釈したものについても, 合成物を稀釈しをるのとつい ても $0.1 \%$ である.

\section{2 硫化䃁素再沈澱法 上述の酸性硝酸銀法は加熱の} 操作を必要としているが，野外における検出法としては 加熱を必要としない方法が望ましいことは勿論である。 筆者らは天然産雄黄と合成硫化砒素との硝酸銀溶液に対 する呈色反纯を比較して観察したところ, 天然産のもの は常温で直ちには呈色を与兄ないのに対し，新しく合成 した硫化砒素は硝酸銀溶液の添加により常温で直ちに黒 色を呈することをみとめた．次に示す第 2 法は試料中の 硫化砣素を一旦水酸化アルカリに溶解し，これより硫化 
砒素を新しく再沈澱させて硝酸銀溶夜との反応を観察す る方法である，合，この方法は操作をできるだけ簡単に するために，再沈澱を完全にするための操作は別に施さ ず，限界惯度も幾分䈅牲にしているが，遊離硫黄中 $1 \%$ $\mathrm{As}_{2} \mathrm{~S}_{3}$ 以上の硫化砣素を含む場合には硝酸銀に対する黒 化度から大体の砒素含有量の推定が可能である長所を有 している.

試薬 (1) $0.1 N$ 水酸化カリウム溶液.

(2) $0.2 N$ 硝酸

(3) $0.1 \mathrm{~N}$ 硝酸銀溶液

(4) アルコール.

操作 試料に $0.1 N$ 水酸化カリウム溶液 $5 \mathrm{cc}$ を加え, 常温でよく振盪した後, $0.2 N$ 硝酸 $5 \mathrm{cc}$ を加え, ガラス 管によって呼気を通じ (備考1), その後 $0.1 N$ 硝酸銀溶液 を約1cc(備考2),アルコールを数滴(借考3) 加え, 振燙後傾 瀉して褪色眯濁液をすてる. 残った沈澱に $0.1 N$ 硝酸銀 溶液 5cc を添加する. 硫化砒素の存在により直ちに黒色 を呈する.

限界漢度 遊離硫黄中 $1 \% \mathrm{As}_{2} \mathrm{~S}_{3}$

備考 (1) 乙の操作は, 生成した硫化水素をできる だけ除去するのが目的である。

（2）硝酸銀溶液の添加により，沈澱物の沈降が促進 される。

（3）アルコールの添加により, 硫黄の䀣濁液が沈降 する.

この方法により, 硫黄中に含まれる硫化砒素の $<1 \%$, 1〜10\%，>10\% の区別が可能である.

3 砒酸銀法 Feigl の著書(6) に記載されている砒酸銀 生成の方法もまたこの目的に適用することができる. 既 述の二方法が何れも硫化砒素中の硫化物硫黄兵硝酸銀と の反応に基いていたのに対して, 本法は硫化砒素中の䂣 素に由来する砒酸塩と硝酸銀との反応である.

試薬 (1) $6 N$ アンモニア水

(2) $0.1 N$ 硝酸銀溶液

（3）過酸化水素水

(4) $1 N$ 醋酸アンモニウム溶液

操作 試料に水 $5 \mathrm{cc}$ を加え, $6 N$ アンモニア水数滴を 添加し, よく振璗後濾過して, 濾液を 2 分し, 一方には $0.1 N$ 硝酸銀溶液を加える. 硫化物硫黄の存在により黒 变する (碚考1).他方には少量の過酸化水素水を加えて加 熱し, 砒素および硫化物硫黄を夫及砒酸塩, 硫酸塩に酸 化する. 冷却後, 少量の醋酸アンモニウム溶液および $0.1 N$ 硝酸銀溶液 $1 \mathrm{cc}$ を加える. 砒素の存在により赤褐 色を呈する.

備考 (1) 遊離硫黄のみの場合も, 冷アンモニア水 に幾分溶解して, 硝酸銀により僅かに同様の呈色を示す。

以上に述べた三つの方法はそれぞれ特長を有し，(1) の酸性硝酸銀法は操作が最も簡単であり, 且つ感底が最 もよく，(2) の硫化砒素再沈澱法は加熱を必要とせず， 且つ硫化砣素の大体の含有量を推定し得る利点があり, (3) の砒酸銀法では直接に砒素を検出し得る点がすぐれ ている.

第 1 表

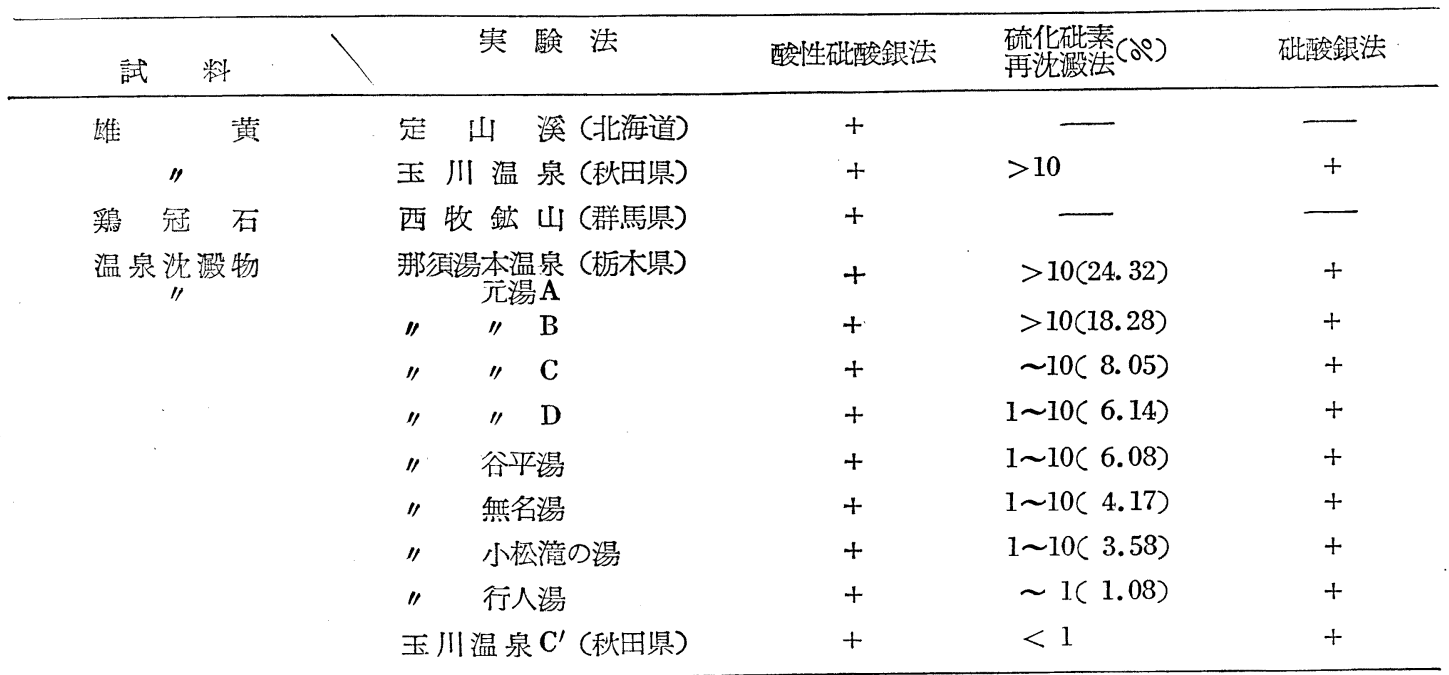

実験例 上述の方法を用い天然産の硫黄華等について硫 化砒素を検出した例を第1表に表示した.表中の記号(†) は硫化砒素の榆出されたものであり, 第 3 行の硫化砒素 再沈澱法の㯗には硫化砣素の含有量の大体の推定值を示 し, 更に括弧内には砒素の定量值から計算した $\mathrm{As}_{2} \mathrm{~S}_{3}$ と
しての百分率の值を比較のために併せ記した。

\section{結 高}

上記の検出反応の際に，妨害になると考它られる元素 として, 第 1 法, 第 2 法に和いては酸性で不溶性の硫化 物を与える元素が一忘問題になるが，これらは何れも， 
第 3 法の際に妨害を及ぼさないから，第 3 法を併用する ことにより，事実上妨害イオンの心配なく，天然産硫化 䂤素の検出が可能である.

これらの三つの方法はそれぞれ特長を有しており，実 験の目的に応じて適当に三法を使い分ければ能率的であ り，更にこれらの方法の二つ以上を併せ用いれば，一層 効果的であることは言を俟たない。

終りに臨みこの研究に要した費用の一部は文部省科 学研究費より支出した。また，現地においては，玉川温 泉については玉川温泉研究会より援助を受け，那須温泉 についてて那須温泉株式会社より数々の援助を受けた。
記して厚く感謝の意を表する。

\section{交献}

(1) 「日本鈗物誌」, 第 3 版, 上巻, 36 (1947).

（2）菅沼市蔵：東京物理学校杂倠誌４４69,25 (1930).

(3) “Dana's System of Mineralogy," 7th, Ed., New York, 1, 268 (1944).

(4) ibid.

(5) C. Doelter, H. Leitmeier : "Handbuch der Mineralchemie, " Band IV, 1. Hälfte, (1926), S. 45.

(6) F. Feigl : "Qualitative Analyse mit Hilfe von TüPfelreaktionen“ 3. Aufl., Leipzig, (1938), S. 190.

\title{
（信越化学工業株式会社直江津工場*）（昭和28年 7 月 7 日受理）
}

\section{石灰窒素分析法の研究 (第 $1 \cdot 2$ 報)}

\section{稲 葉 栄也 \\ Studies on Analysis of Calcium Cyanamide. (I • II)}

\author{
Hideya INABA \\ (Naoetsu Plant of Shin-Etsu Chemical Industry Company)
}

\begin{abstract}
Part 1. An Improvement in the Quantitative Estimation of Dicyandiamide by Harger Method

Results of quantitative estimation of dicyandiamide in calcium cyanamide by various methods do not always give agreement and there are considerable variation. Furthermore, these methods require a considerable time and there are many difficulties in their practical application. The present report deals with the studies on the effects of the amount of sample
\end{abstract}

Part 2. A Rapid Method of Estimation of Dicyandiamide as Guanylurea Nitrate

An improved Harger method described in the first report gave accuracy and rapidity. However, the method was not ideal in point of rapidity and further studies revealed that a satisfactory result was obtained by application of the formation of guanylurea nitrate from reaction of nitric acid. The method is to add a certain amount of nitric acid to an extracted solution

\section{[第 1 報]}

\section{Hargr 氏ジシアンジアミド定量法の改辰}

\section{I 緒}

石灰空素の風化品及び水和石灰空素若くは「オイレー ション」とか「グラニレーション」を行ったものには, 必ず「ジシアンジアミド」を含有し, 往ふにして肥料取 楴法に依る含有制限量（哇素態として 1.2\%）を超過す る仜険があり粒状石正窒素製造上極めて重大なる問題で

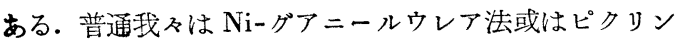

\footnotetext{
* 新渴県直江津町
}

used, concentration of reagents, presence of impurities, and $\mathrm{pH}$ at the time of precipitation temperature and tiltrating condition in Harger method or " silver picrate method" with the result that this method is inaccurate in the presence of impurities, e. g. melamine and guanidine; a suitable method to be applicable in such a case is established with higher accuracy and rapidity in comparison with heretofore known methods. A preliminary report on the corrected values of sulubilities is given.

(Received, July 7, 1953).

of calcium cyanamide, heat the mixture in a sealed container for 15 minutes at $100^{\circ} \mathrm{C}$, the excess of nitric acid being estimated by titrating it with sodium hydroxide with an aim of estimations the amount of dicyandiamide from the amount of nitric acid consumed for the reaction. The time required for the reaction is 3 hours including the extraction, it does not require special reagents and its accuracy is $\pm 3 \%$ of the content.

(Received, July 7. 1953)

酸銀法を使用するのであるが，両者の值は必ずしも一致 しない，我及は当社に和ける粒状石灰空素製造研究の一 環として，「ジシアンジアミド」定量に関する従来の諸 法を検討した. 今回はその内ピクリン酸銀法, 即ち Har ger 法に関し検討した結果及び考案せるとの改良法に つき報告する.

\section{Harger 法の検討}

1) $\mathrm{pH}$ の影響

沈澱生成時に於ける $\mathrm{pH}$ の影響を検するため硝酸添加

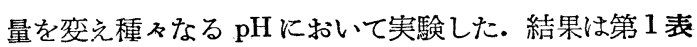

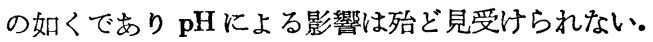

